\title{
Evaluation of Physical and Chemical Properties of Maikunkele Stream for Irrigation Purpose Using Water Quality Index
}

\author{
*1 John J. Musa, ${ }^{2}$ Ebierni Otuaro, ${ }^{3}$ Pius O.O. Dada and ${ }^{4}$ Bello G. Aliyu \\ ${ }^{1}$ Department of Agriculture \& Bioresources Engineering, Federal University of Technology, Minna, Nigeria \\ ${ }^{2}$ Department of Civil Engineering, Maritime University, Okerenkoko, Nigeria \\ ${ }^{3}$ Department of Agricultural and Bioresources Engineering, Federal University of Agriculture, Abeokuta, Nigeria \\ ${ }^{4}$ Department of Agriculture, Federal Ministry of Agriculture and Rural Development, Area 11, Garki, Abuja, Nigeria \\ johnmusa@futminna.edu.ng | dadapoo@funaab.edu.ng $\mid$ \{e.otuaro $\mid$ bellogoro\}@yahoo.com
}

Received: 01-MAY-2021; Reviewed: 29-MAY-2021; Accepted: 14-JUN-2021 http://dx.doi.org/10.46792/fuoyejet.v6i2.628

\begin{abstract}
The study is aimed at using water quality index (WQI) as a standard for determining the suitability of the surface water for irrigation purpose within the Maikunkele Fadama area in Niger State, Nigeria by monitoring five sampling points for five months. The samples were analyzed for includes nitrate $\left(\mathrm{NO}_{3}\right)$, phosphate $\left(\mathrm{PO}_{4}\right)$, sodium $(\mathrm{Na})$, potassium $(\mathrm{K})$, magnesium $(\mathrm{Mg})$, calcium $(\mathrm{Ca})$, manganese $(\mathrm{Mn})$, copper $(\mathrm{Cu})$, zinc $(\mathrm{Zn})$, and iron $(\mathrm{Fe})$, besides other general parameters ( $\mathrm{pH}$, electrical conductivity (EC), total dissolved solids (TDS), alkalinity, total hardness, dissolved oxygen (DO), biological oxygen demand (BOD), chemical oxygen demand (COD), turbidity). The WQI for the parameters under investigation were determined and values compared international standards. The mean temperature value ranged between 29.5 and $30.4^{\circ} \mathrm{C}$, while $\mathrm{pH}$ values of 7.18 maximum and 5.95 minimum were observed for the study location. The electrical conductivity ranged between 174 and $274 \mu \mathrm{Scm}^{-1}$. The mean concentration of calcium ion ranged between 3.68 and $4.44 \mathrm{mgL}^{-1}$. The concentration of Fe was $0.13 \mathrm{mgL}^{-1}$ and $1.48 \mathrm{mgL}^{-1}$. The minimum and maximum values of $\mathrm{Zn}$ are $0.01 \mathrm{mgL}^{-1}$ and $0.17 \mathrm{mgL}^{-1}$ respectively. The Maikunkele Fadama stream had WQI value ranging from 43.469 to 47.120 which fall under good water category, these also conforms to the results obtained from the analysis carried out. It is therefore concluded that the stream water feeding the Maikunkele Fadama farm is fit to be used as irrigation water for the study area as Fadama stream had WQI value ranging from 43.469 to 47.120 thus falling under good water category as far as water quality for irrigation purpose is concerned. Hence, the stream water feeding the Maikunkele fadama farm is fit to be used as irrigation water.
\end{abstract}

Keywords- Agrochemicals, contamination, fadama farming, Irrigation water, water quality index

\section{INTRODUCTION}

A grochemicals (pesticides and fertilizer) stand out as a major development in modern agriculture. They are widely used to save energy and labour, control pest and increase crop yields for food demand of the increasing population and control of vector-borne disease (Adeola, 2012). Despite the positive contribution of agrochemicals to agricultural production, it has been shown in the last few decades that they could also cause negative effects such as cancers, birth defect, reproduction and respiratory problem (Tadesse \& Asferachew, 2008; Claeys et al., 2011). Some other problems related to agrochemical are destruction of the environment such as global warming, depletion of ozone layer, pest migration and bioaccumulation.

Sonika and Rashmi (2014) reported that only $0.1 \%$ of applied pesticides and agrochemicals get to the areas of interest, leaving $99.9 \%$ to impact on the environment. These pesticides can take part in different biological, physical, and chemical processes. Several of these pesticides are known with strong persistence which describes their wide existence in the different sections of environment. As a result of these physical and chemical characteristics and their wide use, many of the agrochemicals end up in subsurface and surface water (Sonika \& Rashmi, 2014). Such agrochemicals constituents are often traced to most surface waters and in increasing number of aquifers (Postigo et al., 2021).

\section{${ }^{*}$ Corresponding Author}

Section A- AGRICULTURAL ENGINEERING \& BIOLOGICAL SCIENCES Can be cited as:

Musa J., Otuaro E., Dada P. and Aliyu B.G. (2021): Evaluation of Physical and Chemical Properties of Maikunkele Stream for Irrigation Purpose Using Water Quality Index, FUOYE Journal of Engineering and Technology (FUOYEJET), 6(2), 10-15. http://dx.doi.org/10.46792/fuoyejet.v6i2.628
Studies on groundwater usage for agricultural activities in Nigeria have shown a significant level of contamination (Egbueri, 2019) however certain agrochemicals when continuously used get to the groundwater with time (Anasco et al., 2010; Musa \& Ahanonu, 2013). This is particularly true for herbicides, especially in developing countries such as Nigeria where Good Agricultural Management Practices (GAMP) are usually not taken into consideration (Ikpesu \& Ariyo, 2013). The agrochemicals drain into surface water and groundwater from the points where they are applied. Researches have shown that agrochemicals get to surface water and groundwater either by runoff, run in and leaching thereby conveying the washed chemicals into either nearby surface water and groundwater. These actions result in serious contamination of water which poses great danger to living things that consume the water. The presence of agrochemicals in surface water in very small quantity negatively affects the life cycle of aquatic organisms within such environs (Rovedatti et al., 2001). Their existence in water body is considered as a potential risk not only to human being but also to the ecosystem (Ravi \& Wantamutte, 2014).

Despite the fact that pesticides are also applied in other sectors, agriculture can undoubtedly be viewed as the most important source of some of these contaminants (Willian, 2008). Agrochemicals' residues found in agricultural produce, water and environmental samples has been a major issue for many years because of their potential risk on human health, persistence and tendency to bio-accumulate (Florin et al., 2009). According to a WHO (2009) report, worldwide there are more than 26 million human pesticide poisonings with about 220,000 deaths annually (Richer, 2002). 
Water quality monitoring has one of the highest priorities in environmental protection policy (Pesce \& Wunderlin, 2000; Simeonov et al., 2002; Sargaonkar and Deshpande 2003; Khan et al., 2003; Chauhan \& Singh, 2010; Effendi \& Romanto, 2015) to control and minimize the incidence of pollutant-oriented problems, and to provide water of appropriate quality to serve various purposes such as drinking water supply, irrigation, recreational and industrial; and to protect the valuable freshwater resources. Traditional approaches to assess water quality are based on comparing experimentally determined parameter values with existing guidelines. However, it does not readily give an overall view of the spatial and temporal trends in the water quality in a watershed (Debels et al., 2005).

The classification, modelling and interpretation of monitoring data are the most important steps in the water quality assessment. The quality is difficult to evaluate from a large number of samples each containing concentrations for many parameters (Almeida et al., 2007). The concept of Water Quality Index (WQI) is based on the comparison of the water quality parameters with respect to regulatory standards and gives a single value to the water quality of a source, which reflects the list of constituents and their concentrations present in a sample (Abbasi, 2002; Khan et al., 2003; Sanchez et al., 2007). It is a mechanism for presenting a cumulatively derived numerical expression defining a certain level of water quality (Bordalo et al., 2006).

The WQI has been considered as one criterion for surface water classifications, based on the use of standard parameters for water characterization. It is a mathematical means of calculating a single value from multiple test results. The index result represents the level of water quality in a given water basin (Avdullahi et al., 2013; Effendi and Romanto, 2015). The objective of this study is to determine the water quality status of the Maikunkele stream using Water Quality Index (WQI).

\section{Materials And Methods}

\subsection{STUDY SITE}

The study was conducted on Maikunkele Stream water in Bosso Local Government Area, Minna, Niger State, Nigeria. Minna, capital of Niger State lies in the savannah zone of the tropics between latitude $8^{\circ} 10^{\prime \prime} \mathrm{N}$ and $11^{\circ} 3^{\prime \prime} \mathrm{N}$ and longitude $3^{\circ} 20^{\prime \prime} \mathrm{E}$ and $7^{\circ} 30^{\prime \prime} \mathrm{E}$. Minna has two distinct seasons: rainy and dry. The rainy season begins in April and ends in October- November of the same year. The average annual rainfall of $1,312 \mathrm{~mm}$ is obtained for the study area with an average temperature of $30{ }^{\circ} \mathrm{C}$ and the average relative humidity of $61.00 \%$ (Musa \& Egharevba, 2009; Ahaneku \& Sadiq, 2014). The Maikunkele stream water is a major source of water in the study area, which is of agricultural and domestic significance. It supplies water for the fadama farmers along its bank for irrigation and for domestic purposes. Some of the activities that are carried out around the study area contaminate the stream. Such activities include domestic waste (sewage), dumping of refuge and agricultural runoff.

\subsection{WATER SAMple Collection}

The samples were randomly collected with purified plastic bottles. The plastic bottles were washed thoroughly with distilled water and dried at room temperature before being put to use for sample collection. The bottles were marked and labelled in reference to the sampling points as stated in the works of Musa \& Ahanonu (2013). Water samples were collected from five points along the stream and replicated five times across each point. Before the collection of water samples at the various points, each bottle was rinsed with the source of water to be collected and firmly corked after sample collection to prevent contamination and they were transported immediately to the laboratory in ice packs.

The samples were then analysed for fifteen physiochemical parameters namely: temperature, $\mathrm{pH}$, conductivity, dissolved oxygen (DO), Biochemical Oxygen Demand (BOD), chemical oxygen demand (COD), total hardness, alkalinity, nitrates $\left(\mathrm{NO}_{3}^{-}\right)$, phosphorus $\left(\mathrm{PO}_{4}\right)$, sodium $(\mathrm{Na})$, potassium $(\mathrm{K})$, Magnesium $(\mathrm{Mg})$, and calcium $(\mathrm{Ca})$ and five heavy metals $(\mathrm{Mn}, \mathrm{Cu}, \mathrm{Zn}, \mathrm{Fe}, \mathrm{Pb})$.

\subsection{Determination OF WATER QUALITY INDEX (WQI)}

Determining the water quality index (WQI) of any source of water is dependent upon the relative importance of the intended use. The calculation of WQI was done using weighted Arithmetic index method. Weighted arithmetic WQI method classified the water quality according to the degree of purity by using the most commonly measured water quality variables. The equations according to the works of Al-Badaii \& Shuhaimi-Othman (2014); Effendi \& Romanto (2015) which recommended the formula for determining WQI are as stated in equation 1

$$
W Q I=\frac{\sum Q_{i} W_{i}}{\sum W_{i}}
$$

While the quality rating scale $\left(Q_{i}\right)$ for each parameter is calculated using the:

$$
Q_{i}=100\left(\frac{V_{i}-V_{o}}{s_{i}-V_{o}}\right)
$$

Where $V_{i}$ is the estimated concentration of the parameter in the analysed water and $V_{o}$ is the ideal value of this parameter in pure water

$V_{o}=0$ (except $\mathrm{pH}$ and DO)

$S_{i}=$ Recommended standard value of parameter

$W_{i}=$ unit weight for each water quality parameter

$$
W_{i}=\frac{K}{s_{i}}
$$

Where $\mathrm{K}=$ proportionality constant $\left(K=\frac{1}{\Sigma\left(\frac{1}{s_{i}}\right)}\right)$

The rating of WQI as stated in the work of Al-Badaii \& Shuhaimi-Othman (2014) is presented in Table 1 below. The results obtained were statistically analysed using the Microsoft office excel of 2013.

Table 1. Showing water quality index grading

\begin{tabular}{lll}
\hline WQI Value & Rating of water Quality & Grading \\
\hline $0-25$ & Excellent Water Quality & A \\
$26-50$ & Good Water Quality & B \\
$51-75$ & Poor Water Quality & C \\
$76-100$ & Very Poor Water Quality & D \\
Above 100 & Unfit for Irrigation Purpose & E \\
\hline
\end{tabular}




\section{Result And Discussion}

All the mean values, maximum, minimum and standard error values of all the parameters for the study area are presented in Table 2. The mean temperature value ranged between $29.5^{\circ} \mathrm{C}$ and $30.4^{\circ} \mathrm{C}$ for the five-study location. The probable cause of variation in temperature of the various water samples may include irrigation activities within the study area and sedimentation. The variations in temperature were not statistically significant at 5\% level. The $\mathrm{pH}$ values observed at the various study points according to the descriptive statistical analysis showed that mean value range between 6.49 and 6.66 with the maximum value of 7.18 and the minimum value of 5.95 both at study location A which shows that the stream is slightly acidic and slightly basic in nature.

The increase in $\mathrm{pH}$ can be attributed to organic pollution and the domestic waste discharge into the stream. The electrical conductivity ranged between 174 and $274 \mu \mathrm{s} / \mathrm{cm}$ which falls within the maximum recommended permissible limit of $300 \mu^{-1}$ allowed for drinking waters as recommended by WHO (2009). The highest electrical conductivity was observed during the second month (February) of collection of samples. This may be due to high introduction of domestic waste water from the neighbouring community.

The lowest value of the dissolved oxygen (DO) was recorded in the month of March which may be due to a one-time rainfall within the study area, thus diluting the waste water from domestic homes from the neighbouring community. DO has been identified as an important parameter which is essential to the metabolism of all aquatic organisms that possess aerobic respiration. The DO values obtained in the study are within recommended WHO (2009) standards. The maximum value observed is $12 \mathrm{mgL}^{-1}$ and the minimum value observed is $6 \mathrm{mgL}^{-1}$ while the mean values ranged between 7.75 and 9.60 $\mathrm{mg} / \mathrm{L}$. This low value can be attributed to the low addition of effluents containing oxidizable organic matter and consequent low biodegradation and decay of vegetation at higher temperature leading to low consumption of oxygen from water. Biochemical oxygen demand (BOD) for the stream ranged between 2.0 and $7.0 \mathrm{mgL}^{-1}$. The increased levels of BOD indicated the nature of chemical pollution within the stream during the dry season. All the study points were observed to have high BOD values, which exceed the recommended WHO (2009) standard value of $5.0 \mathrm{mgL}^{-1}$., thus, leading to decreases in the level of dissolved oxygen. The total hardness $(\mathrm{TH})$ ranged from 49 and $153 \mathrm{mgL}^{-1}$, which are within limits of WHO (2009) standard. Sodium concentration ranged from 2.83 to 5.61 $\mathrm{mgL}^{-1}$. The highest Sodium ion concentration was 4.56 $\mathrm{mgL}^{-1}$ at station $\mathrm{E}$ that is within the permissible limit of 40 $\mathrm{mgL}^{-1}$ for irrigation water.

Magnesium ion concentration had a minimum value of $29.00 \mathrm{mgL}^{-1}$ at point $\mathrm{A}$ with the maximum value of 35.20 $\mathrm{mgL}^{-1}$ at location $\mathrm{E}$. the obtained values for $\mathrm{Mg}$ ion were observed to be higher when compared with the maximum permissible limit of $5 \mathrm{mgL}^{-1}$ for irrigation water. The average mean concentration of Calcium ion ranged between 3.98 and $42.75 \mathrm{mgL}^{-1}$. The highest maximum value of $59.75 \mathrm{mgL}^{-1}$ for calcium ion was obtained in study

location c while the lowest value of $21.08 \mathrm{mgL}^{-1}$ was observed at location $\mathrm{D}$. The obtained values were not within the permissible limits of $20 \mathrm{mgL}^{-1}$ recommended by WHO (2009). The maximum concentration of Fe obtained from location $B$ was $1.48 \mathrm{mgL}^{-1}$ while the minimum value of $0.13 \mathrm{mgL}^{-1}$ was observed at location $\mathrm{E}$. The values of iron concentration in the various water samples were within permissible WHO (2009) limit of $5.00 \mathrm{mgL}^{-1}$.

The mean average values of $\mathrm{Cu}$ at the various locations have all values less than 1 with the lowest values obtained at study locations A, B and D respectively while location $E$ had the highest value of $0.02 \mathrm{mgL}^{-1}$. The observed values found within the study area were within the permissible limit of $0.20 \mathrm{mgL}^{-1}$ as recommended by WHO (2009). The lowest average mean value of $\mathrm{Zn}$ within the study was observed at study location $\mathrm{D}$ to have a value of $0.05 \mathrm{mgL}$ 1 while the maximum values were observed study locations $B$ and $C$ with a value of $0.10 \mathrm{mgL}^{-1}$ was observed at location $D$. This shows that there is a high contamination intensity and strong diffusivity of $\mathrm{Zn}$. The minimum and maximum value of $\mathrm{Zn}$ concentration for the area ranged between 0.01 to a maximum of $0.17 \mathrm{mg} / \mathrm{L}$. Thus, the values of Fe concentration in the water were within the recommended limits of $2.00 \mathrm{mgL}^{-1}$. The concentration of Manganese obtained in the water ranged between $0.01 \mathrm{mgL}^{-1}$ to $0.06 \mathrm{mgL}^{-1}$. However, the highest mean value of Manganese concentration recorded in the study area was $0.035 \mathrm{mgL}^{-1}$. The observed values were within the permissible maximum limit of $0.20 \mathrm{mg} / \mathrm{L}$.

\section{WATER QUALITY INDEX (WQI)}

WQI for each of the samples were analysed by using the weighted arithmetic index using for the various physiochemical parameters (Temperature, $\mathrm{pH}$, Electrical Conductivity, Nitrate, Phosphate, Copper, zinc, Iron, Manganese, Sodium, Potassium, Magnesium and Calcium) are considered. The values for $\mathrm{Q}_{\mathrm{i}}, \mathrm{V}_{\mathrm{i}}, \mathrm{S}_{\mathrm{i}}, \mathrm{W}_{\mathrm{i}}$, and $\left(\mathrm{Q}_{\mathrm{i}} \mathrm{W}_{\mathrm{i}}\right)$ with their respective WQI are presented in Table 3. The observed temperature for study location A had values for $\mathrm{Q}_{\mathrm{i}}, \mathrm{V}_{\mathrm{i}}, \mathrm{S}_{\mathrm{i}}, \mathrm{W}_{\mathrm{i}}$, and $\left(\mathrm{Q}_{\mathrm{i}} \mathrm{W}_{\mathrm{i}}\right)$ as $101.72,29.5,29,0.013$ and 1.322 respectively. The water quality index of station A, B, C, D and E were calculated to be 46.41, 46.16, 43.46, 44.40 and 47.12 respectively.

The suitability of the water samples used for irrigation within the study area was calculated for using the WQI formula and the results obtained were ranked as presented in Table 4. The results show the overall status of the water quality if it is suitable or fit for irrigation purpose. In this study, the WQI for Stations A, B, C, D and E respectively were calculated to be $46.410,46.163,43.469$, 44.403 and 47.120 respectively. Table 2 presents the results from the samples collected from the study area.

Table 4. Water Quality Index Ranking of the Investigated Water Samples

\begin{tabular}{ccc}
\hline Location & WQI & Ranking \\
\hline Station A & 46.410 & Good Water Quality \\
Station B & 46.163 & Good Water Quality \\
Station C & 43.469 & Good Water Quality \\
Station D & 44.403 & Good Water Quality \\
Station E & 47.120 & Good Water Quality \\
\hline
\end{tabular}




\begin{tabular}{|c|c|c|c|c|c|c|c|c|c|c|c|c|c|c|c|c|c|c|c|}
\hline $\begin{array}{l}\text { Statio } \\
\mathrm{n}\end{array}$ & $\begin{array}{l}\text { Statistica } \\
1 \text { tool }\end{array}$ & $\begin{array}{l}\text { Temp } \\
\text { oC }\end{array}$ & $\mathrm{pH}$ & Cond & $\begin{array}{l}\mathrm{DO} \\
\mathrm{mg} / \mathrm{L}\end{array}$ & $\begin{array}{l}\mathrm{BOD} \\
\mathrm{mg} / \mathrm{L}\end{array}$ & $\begin{array}{l}\mathrm{COD} \\
\mathrm{mg} / \mathrm{L}\end{array}$ & $\mathrm{TH} \mathrm{mg} / \mathrm{L}$ & $\begin{array}{l}\text { Alkali } \\
\mathrm{mg} / \mathrm{L}\end{array}$ & $\begin{array}{l}\mathrm{NO}_{3} \\
\mathrm{mg} / \mathrm{L}\end{array}$ & $\begin{array}{l}\mathrm{PO}_{4} \\
\mathrm{mg} / \mathrm{L}\end{array}$ & $\begin{array}{l}\mathrm{Na} \\
\mathrm{mg} / \mathrm{L}\end{array}$ & $\mathrm{K} \mathrm{mg/L}$ & $\begin{array}{l}\mathrm{Mg} \\
\mathrm{mg} / \mathrm{L}\end{array}$ & Ca mg/L & $\begin{array}{l}\mathrm{Mn} \\
\mathrm{mg} / \mathrm{L}\end{array}$ & $\begin{array}{l}\mathrm{Cu} \\
\mathrm{mg} / \mathrm{L}\end{array}$ & $\begin{array}{l}\mathrm{Zn} \\
\mathrm{mg} / \mathrm{L}\end{array}$ & $\begin{array}{l}\mathrm{Fe} \\
\mathrm{mg} / \mathrm{L}\end{array}$ \\
\hline \multirow{4}{*}{ A } & Mean & 29.50 & 6.50 & 225.50 & 7.50 & 4.00 & 202.93 & 98.00 & 64.00 & 0.15 & 0.09 & 3.87 & 4.22 & 25.30 & 40.58 & 0.04 & 0.005 & 0.08 & 1.11 \\
\hline & $\begin{array}{l}\text { Maximu } \\
\mathrm{m}\end{array}$ & 30.00 & 7.18 & 258.00 & 8.00 & 5.00 & 401.00 & 115.00 & 78.00 & 0.18 & 0.12 & 4.90 & 6.74 & 29.00 & 47.26 & 0.05 & 0.01 & 0.13 & 1.33 \\
\hline & $\begin{array}{l}\text { Minimu } \\
\mathrm{m}\end{array}$ & 29.00 & 5.95 & 186.00 & 7.00 & 3.00 & 4.86 & 81.00 & 50.00 & 0.12 & 0.06 & 2.83 & 1.70 & 21.40 & 33.90 & 0.03 & 0.00 & 0.03 & 0.88 \\
\hline & $\mathrm{SD}$ & 0.57 & 0.50 & 29.68 & 0.50 & 0.95 & 197.68 & 16.54 & 11.88 & 0.02 & 0.02 & 2.85 & 2.24 & 3.83 & 6.56 & 0.01 & 0.01 & 0.04 & 0.18 \\
\hline \multirow{4}{*}{ B } & Mean & 30.50 & 6.51 & 241.50 & 8.00 & 3.50 & 5.15 & 103.00 & 55.00 & 0.13 & 0.06 & 3.77 & 3.41 & 2.70 & 42.75 & 0.03 & 0.00 & 0.10 & 0.93 \\
\hline & $\begin{array}{l}\text { Maximu } \\
\mathrm{m}\end{array}$ & 32.00 & 6.74 & 274.00 & 8.00 & 5.00 & 6.26 & 138.00 & 84.00 & 0.15 & 0.08 & 4.33 & 6.36 & 32.40 & 56.18 & 0.06 & 0.00 & 0.17 & 1.48 \\
\hline & $\begin{array}{l}\text { Minimu } \\
\mathrm{m}\end{array}$ & 29.00 & 6.28 & 209.00 & 8.00 & 2.00 & 4.03 & 68.00 & 26.00 & 0.11 & 0.03 & 3.20 & 1.28 & 16.80 & 29.33 & 0.01 & 0.00 & 0.03 & 0.19 \\
\hline & $\mathrm{SD}$ & 1.09 & 0.18 & 26.90 & 0.00 & 1.09 & 0.79 & 29.64 & 22.00 & 0.01 & 0.02 & 0.46 & 2.21 & 7.31 & 11.69 & 0.02 & 0.00 & 0.05 & 0.49 \\
\hline \multirow{4}{*}{ C } & Mean & 30.50 & 6.72 & 208.10 & 9.00 & 4.50 & 5.66 & 107.50 & 62.00 & 0.10 & 0.06 & 4.39 & 3.15 & 2.37 & 3.98 & 0.03 & 0.01 & 0.10 & 0.97 \\
\hline & $\begin{array}{l}\text { Maximu } \\
\mathrm{m}\end{array}$ & 31.00 & 6.80 & 242.00 & 12.00 & 7.00 & 7.97 & 153.00 & 96.00 & 0.11 & 0.09 & 5.36 & 6.03 & 34.70 & 59.75 & 0.05 & 0.02 & 0.17 & 1.40 \\
\hline & $\begin{array}{l}\text { Minimu } \\
\mathrm{m}\end{array}$ & 30.00 & 6.40 & 174.00 & 6.00 & 2.00 & 3.35 & 62.00 & 28.00 & 0.08 & 0.03 & 3.41 & 1.78 & 14.90 & 24.90 & 0.02 & 0.00 & 0.07 & 0.24 \\
\hline & $\mathrm{SD}$ & 0.54 & 0.17 & 27.89 & 3.28 & 2.30 & 1.99 & 36.00 & 27.57 & 0.01 & 0.02 & 0.81 & 1.69 & 7.77 & 13.35 & 0.01 & 0.01 & 0.03 & 0.44 \\
\hline \multirow{4}{*}{ D } & Mean & 30.00 & 6.79 & 199.50 & 9.00 & 5.00 & 6.20 & 84.50 & 49.00 & 0.13 & 0.05 & 3.89 & 3.56 & 21.65 & 34.84 & 0.02 & 0.01 & 0.07 & 1.28 \\
\hline & $\begin{array}{l}\text { Maximu } \\
\mathrm{m}\end{array}$ & 32.00 & 7.25 & 223.00 & 10.00 & 6.00 & 7.28 & 120.00 & 76.00 & 0.16 & 0.06 & 4.88 & 5.22 & 31.20 & 48.60 & 0.01 & 0.01 & 0.12 & 1.36 \\
\hline & $\begin{array}{l}\text { Minimu } \\
\mathrm{m}\end{array}$ & 28.00 & 6.32 & 176.00 & 8.00 & 4.00 & 5.11 & 49.00 & 22.00 & 0.09 & 0.03 & 2.90 & 1.90 & 12.10 & 21.08 & 0.03 & 0.00 & 0.01 & 1.19 \\
\hline & $\mathrm{SD}$ & 1.14 & 0.32 & 18.52 & 1.09 & 0.83 & 0.87 & 26.74 & 21.81 & 0.03 & 0.01 & 0.70 & 1.38 & 7.47 & 10.57 & 0.04 & 0.00 & 0.03 & 0.44 \\
\hline \multirow{4}{*}{ E } & Mean & 30.00 & 6.65 & 233.50 & 8.00 & 3.50 & 4.94 & 100.00 & 58.50 & 0.10 & 0.07 & 4.50 & 3.78 & 24.55 & 41.34 & 0.02 & 0.04 & 0.50 & 0.65 \\
\hline & $\begin{array}{l}\text { Maximu } \\
\mathrm{m}\end{array}$ & 32.00 & 6.90 & 258.00 & 10.00 & 4.00 & 5.96 & 144.00 & 88.00 & 0.14 & 0.09 & 5.61 & 5.35 & 35.20 & 58.58 & 0.01 & 0.07 & 0.11 & 1.16 \\
\hline & $\begin{array}{l}\text { Minimu } \\
\mathrm{m}\end{array}$ & 28.00 & 6.40 & 209.00 & 6.00 & 3.00 & 3.91 & 56.00 & 29.00 & 0.06 & 0.05 & 3.39 & 2.20 & 13.90 & 24.10 & 0.02 & 0.00 & 0.88 & 0.13 \\
\hline & SD & 1.48 & 0.17 & 18.88 & 2.00 & 0.54 & 0.93 & 38.44 & 28.50 & 0.03 & 0.01 & 0.83 & 1.20 & 9.31 & 15.37 & 0.05 & 0.03 & 0.02 & 0.42 \\
\hline
\end{tabular}




\begin{tabular}{|c|c|c|c|c|c|c|c|c|c|c|c|c|c|c|c|c|}
\hline Sample & Parameters & Temp. & $\mathrm{pH}$ & $\begin{array}{c}\text { E. } \\
\text { cond. } \\
(\mu \mathrm{s} / \mathrm{cm})\end{array}$ & $\begin{array}{c}\mathrm{N}_{3} \\
(\mathrm{mg} / \mathrm{L})\end{array}$ & $\begin{array}{c}\mathrm{P}_{4} \\
(\mathrm{mg} / \mathrm{L})\end{array}$ & $\begin{array}{c}\mathrm{Cu} \\
(\mathrm{mg} / \mathrm{L})\end{array}$ & $\begin{array}{c}\mathrm{Zn} \\
(\mathrm{mg} / \mathrm{L})\end{array}$ & $\begin{array}{c}\mathrm{Fe} \\
(\mathrm{mg} / \mathrm{L})\end{array}$ & $\begin{array}{c}\mathrm{Mn} \\
(\mathrm{mg} / \mathrm{L})\end{array}$ & $\begin{array}{c}\mathrm{Na} \\
(\mathrm{mg} / \mathrm{L})\end{array}$ & $\begin{array}{c}\mathrm{K} \\
(\mathrm{mg} / \mathrm{L})\end{array}$ & $\begin{array}{c}\mathrm{Mg} \\
(\mathrm{mg} / \mathrm{L})\end{array}$ & $\begin{array}{c}\mathrm{Ca} \\
(\mathrm{mg} / \mathrm{L})\end{array}$ & Total & $\begin{array}{c}\mathrm{WQI}= \\
\sum \mathrm{QiWi} / \Sigma W \mathrm{i}\end{array}$ \\
\hline \multirow{5}{*}{$\mathrm{A}$} & Observed values $\left(V_{i}\right)$ & 29.5 & 6.5 & 225.5 & 0.15 & 0.08 & 0.002 & 0.08 & 1.09 & 0.03 & 3.93 & 3.43 & 2.53 & 4.08 & & \multirow{5}{*}{$\begin{array}{c}45.97 / 0.9905= \\
46.410\end{array}$} \\
\hline & standard values $\left(\mathrm{S}_{\mathrm{i}}\right)$ & $25-29$ & $6.5-8.4$ & 250 & 30 & 2 & 5 & 2 & 5 & 5 & 40 & 2 & 5 & 20 & & \\
\hline & Quality rating $\left(\mathrm{Q}_{\mathrm{i}}\right)$ & 101.72 & 77.38 & 90.2 & 0.5 & 4 & 0.04 & 4 & 21.8 & 0.6 & 9.83 & 171.5 & 50.6 & 20.4 & & \\
\hline & Unit weight $\left(\mathrm{W}_{\mathrm{i}}\right)$ & 0.013 & 0.046 & 0.0015 & 0.012 & 0.194 & 0.077 & 0.194 & 0.077 & 0.077 & 0.0009 & 0.194 & 0.077 & 0.019 & 0.9905 & \\
\hline & $\left(\mathrm{Q}_{\mathrm{i}} \mathrm{W}_{\mathrm{i}}\right)$ & 1.322 & 3.559 & 0.135 & 0.006 & 0.776 & 0.003 & 0.776 & 1.678 & 0.046 & 0.088 & 33.271 & 3.896 & 0.387 & 45.97 & \\
\hline \multirow{5}{*}{ B } & $\begin{array}{l}\text { Observed values } \\
\left(V_{i}\right)\end{array}$ & 30.2 & 6.49 & 235.8 & 0.12 & 0.06 & 0 & 0.09 & 0.93 & 0.03 & 3.81 & 3.41 & 2.7 & 4.44 & & \multirow{5}{*}{$\begin{array}{c}45.725 / 0.9905= \\
46.163\end{array}$} \\
\hline & standard values $\left(\mathrm{S}_{\mathrm{i}}\right)$ & $25-29$ & $6.5-8.4$ & 250 & 30 & 2 & 5 & 2 & 5 & 5 & 40 & 2 & 5 & 20 & & \\
\hline & Quality rating $\left(\mathrm{Q}_{\mathrm{i}}\right)$ & 104.13 & 77.26 & 94.32 & 0.4 & 3 & 0 & 4.5 & 18.6 & 0.6 & 9.52 & 170.5 & 54 & 22.2 & & \\
\hline & Unit weight $\left(\mathrm{W}_{\mathrm{i}}\right)$ & 0.013 & 0.046 & 0.0015 & 0.012 & 0.194 & 0.077 & 0.194 & 0.077 & 0.077 & 0.0009 & 0.194 & 0.077 & 0.019 & 0.9905 & \\
\hline & $\left(\mathrm{Q}_{\mathrm{i}} \mathrm{W}_{\mathrm{i}}\right)$ & 1.353 & 3.553 & 0.141 & 0.0048 & 0.582 & 0 & 0.873 & 1.432 & 0.046 & 0.085 & 33.077 & 4.158 & 0.421 & 45.725 & \\
\hline \multirow{5}{*}{ C } & $\begin{array}{l}\text { Observed values } \\
\left(V_{i}\right)\end{array}$ & 30.4 & 6.64 & 208.2 & 0.1 & 0.05 & 0.008 & 0.1 & 0.97 & 0.03 & 3.96 & 3.15 & 2.37 & 3.98 & & \multirow{5}{*}{$\begin{array}{c}43.057 / 0.9905= \\
43.469\end{array}$} \\
\hline & standard values $\left(\mathrm{S}_{\mathrm{i}}\right)$ & $25-29$ & $6.5-8.4$ & 250 & 30 & 2 & 5 & 2 & 5 & 5 & 40 & 2 & 5 & 20 & & \\
\hline & Quality rating $\left(\mathrm{Q}_{\mathrm{i}}\right)$ & 104.82 & 79.04 & 83.28 & 0.33 & 2.5 & 0.16 & 5 & 19.4 & 0.6 & 9.9 & 157.5 & 50.6 & 20.4 & & \\
\hline & Unit weight $\left(\mathrm{W}_{\mathrm{i}}\right)$ & 0.013 & 0.046 & 0.0015 & 0.012 & 0.194 & 0.077 & 0.194 & 0.077 & 0.077 & 0.0009 & 0.194 & 0.077 & 0.019 & 0.9905 & \\
\hline & $\left(\mathrm{Q}_{\mathrm{i}} \mathrm{W}_{\mathrm{i}}\right)$ & 1.362 & 3.635 & 0.124 & 0.003 & 0.485 & 0.012 & 0.97 & 1.493 & 0.046 & 0.089 & 30.555 & 3.896 & 0.387 & 43.057 & \\
\hline \multirow{5}{*}{$\mathrm{D}$} & $\begin{array}{l}\text { Observed values } \\
\left(\mathrm{V}_{\mathrm{i}}\right)\end{array}$ & 30.4 & 6.66 & 207.4 & 0.12 & 0.04 & 0.02 & 0.06 & 0.92 & 0.06 & 3.89 & 3.35 & 2.23 & 3.68 & & \multirow{5}{*}{$\begin{array}{c}43.982 / 0.9905= \\
44.403\end{array}$} \\
\hline & standard values $\left(\mathrm{S}_{\mathrm{i}}\right)$ & $25-29$ & $6.5-8.4$ & 250 & 30 & 2 & 5 & 2 & 5 & 5 & 40 & 2 & 5 & 20 & & \\
\hline & Quality rating $\left(\mathrm{Q}_{\mathrm{i}}\right)$ & 104.82 & 79.28 & 83.2 & 0.4 & 2 & 0.04 & 3 & 18.6 & 1.2 & 9.72 & 167.5 & 44.6 & 18.4 & & \\
\hline & Unit weight $\left(\mathrm{W}_{\mathrm{i}}\right)$ & 0.013 & 0.046 & 0.0015 & 0.012 & 0.194 & 0.077 & 0.194 & 0.077 & 0.077 & 0.0009 & 0.194 & 0.077 & 0.019 & 0.9905 & \\
\hline & $\left(\mathrm{Q}_{\mathrm{i}} \mathrm{W}_{\mathrm{i}}\right)$ & 1.362 & 3.646 & 0.124 & 0.004 & 0.388 & 0.003 & 0.582 & 1.416 & 0.092 & 0.087 & 32.495 & 3.434 & 0.349 & 43.982 & \\
\hline \multirow{5}{*}{ E } & $\begin{array}{l}\text { Observed values } \\
\left(\mathrm{V}_{\mathrm{i}}\right)\end{array}$ & 29.8 & 6.65 & 232.6 & 0.16 & 0.06 & 0.016 & 0.068 & 0.87 & 0.06 & 4.56 & 3.58 & 2.37 & 3.99 & & \multirow{5}{*}{$\begin{array}{c}46.673 / 0.9905= \\
47.120\end{array}$} \\
\hline & standard values $\left(\mathrm{S}_{\mathrm{i}}\right)$ & $25-29$ & $6.5-8.4$ & 250 & 30 & 2 & 5 & 2 & 5 & 5 & 40 & 2 & 5 & 20 & & \\
\hline & Quality rating $\left(\mathrm{Q}_{\mathrm{i}}\right)$ & 102.75 & 79.16 & 93.04 & 0.53 & 3 & 0.32 & 3.4 & 17.4 & 1.2 & 11.4 & 179 & 47.4 & 19.95 & & \\
\hline & Unit weight $\left(\mathrm{W}_{\mathrm{i}}\right)$ & 0.013 & 0.046 & 0.0015 & 0.012 & 0.194 & 0.077 & 0.194 & 0.077 & 0.077 & 0.0009 & 0.194 & 0.077 & 0.019 & 0.9905 & \\
\hline & $\left(\mathrm{Q}_{\mathrm{i}} \mathrm{W}_{\mathrm{i}}\right)$ & 1.335 & 3.641 & 0.139 & 0.006 & 0.582 & 0.024 & 0.659 & 1.339 & 0.092 & 0.102 & 34.726 & 3.649 & 0.379 & 46.673 & \\
\hline
\end{tabular}




\section{CONCLUSION}

Some of the physico-chemical parameters of the Maikukele fadama stream water was assessed and the stream water quality status was evaluated using weighted arithmetic mean water quality index. Based on the data generated from this study, it can be concluded that the stream water can be ranked as good, because almost all the parameters are within the limits of the established standard of WHO (2009). Thus, the stream does not require any treatment before being used for irrigation purposes. It is therefore recommended that the stream can be used for irrigation activities but the WQI of the stream be continuously monitored so as to ensure the quality of water do not deteriorate.

\section{REFERENCES}

Abbasi, S.A. (2002). Water quality indices, state of the art report. Scientific contribution No. INCOH/SAR-25/2002.Roorkee: INCOH, National Institute of Hydrology, p. 73

Adeola, R.G. (2012). Perceptions of Environmental Effects of Pesticides use in vegetable Production by Famers in Ogbomoso. Global Journal of Science Frontier Research, Agriculture and Biology, Volume 12: 72-78.

Ahaneku, I.E., \& Sadiq, B. O. (2014). Assessment of Heavy Metals in Nigeria Agricultural soil. Polish Journal of Environmental studies Vol. 23, No.4, Pp. 1092

Almeida, C.A., Quintar, S., Gonzalez, P., \& Mallea, M.A., (2007). Influence of urbanization and tourist activities on the water quality of the Potrero de los Funes River (San Luis Argentina). Environmental Monitoring and Assessment, 133: 459-465.

Anasco, N., Uno, S.O., Koyama, J., Matsuoka, T., \& Kuwahara, N. (2010). Assessment of Pesticides Residues in Freshwater Areas Affected by Rice Paddy Effluents in Southern Japan. Environmental Monitoring and Assessment 160 (1). Pp. 371-383.

Avdullahi, S., Fejza, I., Tmava, A., Rama, M., \& Hetemi, M. (2013). Assessment of Heavy Metal in the Water Springs, Stan Terg, Kosovo. International Journal of Engineering and Applied Sciences, Vol. 2, No. 4: 12-17

Bordalo, A.A., Teixeira, R., \& Wiebe, W.J., (2006). A water quality index applied to an international shared river basin: the case of the Douro River. Environ. Manage, 38: 910-920.

Chauhan, A., \& Singh, S. (2010). Evaluation of Ganga water for drinking purpose by water quality index at Rishikesh, Uttarakhand, India Report opinion, 2 (9). 53-61

Claeys, W.L., Jean-Francois, S., Bragard, C., Maghuin-Rogister, G., Luc, P. \& Schiffers, B., (2011). Exposure of several Begium consumers groups to pesticide residue through fresh fruit and vegetable consumption food contamination. Food Control, 22: 508516.

Debels P, Figueroa R, Urrutia R, Barra R, \& Niell X, (2005). Evaluation of water quality in the Chilla'n River (Central Chile) using physicochemical parameters and a modified water quality index, Environmental Monitoring and Assessment, 110:301-322.

Effendi, H., \& Romanto, Y. W. (2015). Water quality status of Ciambulawung River, Banten Province, based on pollution index and NSF-WQI. The 1st International Symposium on LAPAN-IPB Satellite for Food Security and Environmental Monitoring. Procedia Environmental Sciences 24: 228 - 237. doi: 10.1016/j.proenv.2015.03.030

Egbueri, J. C. (2019). Evaluation and characterization of the groundwater quality and hydrogeochemistry of Ogbaru farming district in southeastern Nigeria. SN Applied Sciences, 1(8), 1-16.

Florin, T., Zaharie M. \& Mircea, V. (2009). Identification and Measurement of Pesticides Contaminants in food products by electron impact GC/MS. Journal of Physics: 182, doi:10.1088/17426596/182/1/012043
Ikpesu, T.O. \& Ariyo A.B. (2013). Health Implication of Excessive use and Abuse of Pesticide. Journal of Environmental Management and Public Safety. Volume 2(5). Pp. 180-188.

Khan, F., Husain, T., \& Lumb, A., (2003). Water quality evaluation and trend analysis in selected watersheds of the Atlantic region of Canada. Environmental Monitoring and Assessment, 88: 221-242.

Musa, J. J., \& Ahanonu, J. J. (2013). Quality Assessment of Shallow Groundwater in Some Selected Agrarian Communities in Patigi Local Government Area, Nigeria. International Journal of Basics and Applied Sciences, Vol. 01, No. 03, 548-563

Musa, J. J., \& Egharevba, N. A., (2009): Soil grouping of the Federal University Technology, Minna, Main Campus, Using Infiltration Rates. Assumption University Journal of Technology 13(1): 19 - 28.

Pesce, S.F., \& Wunderlin, D.A., (2000). Use of water quality indices to verify the impact of Córdoba city (Argentina) on SuquíaRiver. Water Research, 34: 2915-2926.

Postigo, C., Ginebreda, A., Barbieri, M. V., Barceló, D., MartínAlonso, J., de la Cal, A., Boleda, M. R., Otero, N, Carrey, R., Solà, V., \& de Alda, M. L. (2021). Investigative monitoring of pesticide and nitrogen pollution sources in a complex multi-stressed catchment: The lower Llobregat River basin case study (Barcelona, Spain). Science of The Total Environment, 755, 142377.

Ravi, R.K.N \& Wantamutte, A.S. (2014). Practice of Pesticides use among the Famers of Kangrali Village in Belgium. International Journal of Interdiscipilinary and Multidisciplinary Studies. Volume 5, Pp. 202-207.

Richer, E.D. (2002). Acute Human Poising. In Encyclopaedia of Pest Management. Dekker, New York. Pp. 3-6. 